\title{
Non-seminomatous germ cell tumor of testis
}

INSERM

\section{Source}

INSERM. (1999). Orphanet: an online rare disease and orphan drug data base. Nonseminomatous germ cell tumor of testis. ORPHA:363494

Testicular non seminomatous germ cell tumor describes a group of testicular germ cell tumors (see this term) occurring in the third decade of life (mean age: 25 years) with a usually painless unilateral mass in the scrotum or in some cases with gynaecomastia and/or back and flack pain and characterized by a more agg ressive clinical course than testicular seminomatous germ cell tumors (see this term) with rapid involvement of blood vessels and a poorer prognosis. Histologically, they can be either undifferentiated (embryonal carcinoma), differentiated (teratoma, yolk sac tumor, choriocarcinoma), or can consist of a mixture of seminomatous and nonseminomatous components. 